\title{
Impact of Organizational Culture to Improve Audit Quality Assurance in the Public Sector
}

\author{
Waleed Khalid Salih ${ }^{1}$, Dr. Daw Tin Hla ${ }^{2}$ \\ ${ }^{1,2}$ (Departmentof Accounting and finance, Faculty of Economics and Business/University Malaysia Sarawak)
}

\begin{abstract}
Prior studies evidence the influence of organizational culture on the behavior of the individual and the organization and indicated that organizational culture is required for successful development of current organizations. In this context, culture has a key role in the manner which employees behave, communicate, relate and cooperate with their peers and their successful performance. Moreover, organizational culture could play a role in having employees acclimatized to the aims of the organization. The presumption in the international literature concerning culture and the process of audit is that culture affects the audit environment, and ultimately the audit process outcome.

In the past few years, quality audits have risen to the fore as a mechanism to assess the quality assurance effectiveness, and more importantly to evaluate the adherence to established quality standards. The aim behind quality assurance is to assist in guaranteeing that the audit products and services satisfy the established international best practices and the stakeholders' needs as opposed to criticizing particular audit systems. The study findings showed that organizational culture is the heart of the organizational activities that has a significant effect on its effectiveness and its products/services in terms of quality. Moreover, the quality assurance review programs are developed to assure the public that auditors have to maintain a specific degree of competence in their practical work in public offices.
\end{abstract}

Keywords: Organizational Culture, Quality Assurancereview programs.

\section{Introduction}

In the past few years, quality audits have taken to the fore of mechanisms used for the assessment of the quality assurance effectiveness and for the assessment of adherence to established quality standards (Karapetrovic\&Willborn, 2000). In regards to this programs dedicated to quality assurance review are developed to assure the public that auditors do maintain a great degree of practical competence. Such programs are however relatively new in the public accounting industry. The origin of the programs in the U.S. can be traced back to voluntary programming in the mid-1970s and has since evolved to become mandatory in 1988. The premise of practice monitoring was disseminated to other countries in the later parts of 1980s and early parts of 1990s, and in the current times countries are increasingly establishing it (Alkafaji, 2007) as a requirement of increased competence (Knatterud et al., 1998).

In theory, the quality assurance system implementation leads to higher trust of clients in the organization's operations and products, and services (Fuentes, et al., 2000). Such an implementation calls for an effective framework that functions as a reference standard for the assessment of the system in that it has been developed in a structured, complete and effective manner (Venter \& Du Bruyn, 2002). The quality assurance primary aim is instead of criticizing specific systems, to ensure that the audit products/services satisfy the established international best practices and to satisfy stakeholders' needs (ASOSAI, 2009). Audit of low-quality leads to business failure, which in turn may lead to other results including business failure, corruption, among others (Kayrak, 2008). Failed audits have led to debates as to the new reinforcements to be established to ensure audit quality (Hagman\&Persson, 2014).

Prior studies evidenced the effect of organizational culture on individual and organizational behavior, and that the former is a requirement for successful and developed organizations in the current times (Buble, 2012), and that organizational culture could be employed to keep employees under control and acclimatized towards the goals of the organization (Adewale\&Anthonia, 2013). Culture has a crucial role in the employees' behavior in terms of their communication, team work and successful performance (Badea, 2013). Also, organizational culture is the heart of the activities in the organization and it influences it overall effectiveness and the product/service quality (Adewale\&Anthonia, 2013). It is presumed by the literature concerning culture and the audit process that the culture of the country influences its audit environment, which ultimately influences the audit process results (Wang \& Hell, 2009).

The organizations in the public sector are deemed to be hold more accountability compared to those in the private sector as the former is entrusted with the government budget that is meant for public funds (Cukier et al., 2012). In recent times, increasing significance is placed on SAIs conducting public sector quality audit - as their role is to carry out audit and provide assurance services that work towards enhancing public sector and 
government accountability. In fact, SAIs are important to ensure that a continuous chain of accountability is present between parliament and government, with the inclusion of government agencies, authorities, firms and controlled institutions (Funnell, 1997). SAIs including auditors, auditor courts, government and public sectors play a key role in improving the accountability of government and the public sector (Clark et al., 2007).

\section{Literature Review on Organizational Culture}

The effect of organizational culture on auditing has been examined by studies in literature. For instance, Al-Alawi et al. (2007) examined the role of specific organizational culture factors in successful knowledge sharing. These include interpersonal trust, staff communication, information systems, rewards and organizational structure - they were all found to play a key role in defining the staff relationships, and in realizing the potential to solve issues concerning knowledge sharing. They also found that organizational culture positively relates to knowledge sharing and it could result in positive outcomes in organizational prosperity.

In another study, Wright (2009) looked into the way organizational culture influences the use of operational internal audit and the response of operational internal audit. The author found the operational internal auditors having a significant cultural orientation towards rules and procedures had a tendency to effectively serve the organizations they work in. Moreover, Testa and Sipe (2013) contended that with the increase of competition and with the demands of the customers, organizational leaders are faced with the increasing issue of how to sustain their competitive advantage, with one of the methods being to develop a compelling organizational culture. According to them, organizational culture needs improvement if the organization is desirous of establishing a competitive advantage.

Lastly, Kustinah (2013) investigated the effect of organizational culture on the behavior of employees in different categories and the significance of its relationship with organizational culture in terms of determining how the latter influences the audit quality of certified public accountants. His findings showed that organizational culture positively and significantly impact the quality of audit. Improved audit quality stems from the auditors that are free of stress when auditing, less work and a healthy competition. The reviewed studies in literature shows the importance of organizational culture and its influence on audit practices as it brings about the organization's provision of effective services, optimum process of decision-making, competitive advantage and prosperity, and ultimately, it affects audit quality.

\subsection{Literature Review on Audit Quality Assurance}

Past studies made attempts to determine the effectiveness of the audit quality assurance using different research methods. Generally, the authors obtained an overall general understanding of audit quality assurance. In this section, prior studies dedicated to the subject are identified and described. To begin with, Venter and Du Bruyn (2002), quality assurance reviews of internal auditing function provided firms with an extensive and qualitative review of their auditing procedures and recommended that they enhanced their controls, minimize their risks and launch successful practices. In another related study, Marais (2004) determined how to maintain and enhance the internal auditing function quality, and assess its efficiency and effectiveness through internal and external means. The author revealed that an audit quality programmer's main goal is to guarantee and enhance the internal auditing function quality and assess its effectiveness and efficiency through both means.

Moreover, Russell and Armitage (2006) assessed peer review effectiveness in monitoring assurance quality in the context of the U.S. and found that some auditors consider a peer reviewer to be allowed in selfselection engagement. Similarly, Morrison and Shough (2009) contended that practitioners consider peer reviews to be advantageous to improving auditing practices and that it leads to enhanced engagement quality assurance. In a related study, Chambers (2006) provided a discussion of the developments and challenges in providing quality assurance services in external auditing in an attempt to contribute to public confidence on external and internal audit quality and to pinpoint fraud indicators.

\section{Meaning of Organizational Culture}

Organizational culture is deemed to be the best way to facilitate knowledge management and organizational innovation, as it determines the values and beliefs underlying the work systems, and as such, it can encourage/prevent knowledge creation and sharing (Gold et al., 2001). Organizational culture refers to the fundamental assumptions that the organization has learnt when coping with the environment and finding solutions to problems concerning external adaptation and internal integration - these are learned by new members of the organization (Park et al., 2004; Al-Alawi et al., 2007).

Culture forms the ideas, customs, beliefs, attitudes, skills, arts of a specific people in a specific time and that one of the most effective places to begin enhancements in an organization is its culture. Majority of studies revealed the effect of organizational culture on individual and organizational behavior, and how it is required for successful development of current organizations (Buble, 2012). This is because culture has a key role in the behavior, communication, relationship and team work as well as successful performance of 
employees (Badea, 2013). Organizational culture could also be the element that keeps employees under control and acclimatized to the aims and goals of the organization (Adewale\&Anthonia, 2013).

More specifically, according to Adewale and Anthonia (2013), organizational culture is the heart of the organization's activities that impacts its overall effectiveness and its products and services quality. It is presumed in international literature that a country's culture influences its audit environment, and in turn, this affects the result of the audit process (Wang \& Hell, 2009).

\section{Important of Organizational Culture.}

An organization's culture an important component of organizational success in general. According to the results reported by Corbett et al. (2000), different management cultures relate with quality indicators and that understanding such relationship would enable managers to develop effective and competitive organizations. Also, organizational culture is positively related to knowledge sharing in firms, and it could result in positive outcomes and as such, culture is considered to be a critical success factor of any firm (Al-Alawi et al., 2007).

Organizational culture was also addressed in Wright's (2009) study where the author examined its influence on internal audit quality. He found that culture positively relates with the internal auditing quality, indicating that internal auditors having a strong cultural orientation towards rules and procedures will have better performance. In a related study, Abu-Jarad et al. (2010) stressed on measuring organizational culture while shedding a light on the relevant studies concerning the topic. They revealed that organizational culture significantly influences the organization as a whole and its leads to enhanced performance.

The dimensions of organizational culture and its association with TQM practices of quality were analyzed by Baird et al. (2011). They found cultural dimension to be the top factor that improves the employment of TQM practices and operational performance. However, in Testa and Sipe's (2013) indicate to important create an effective culture in the organization. According to the authors, developing such a culture could be significant for the organization's obtaining of competitive advantage.

In relation to the above studies, Svanberg and Ohman (2013) investigated the threats to audit quality that arises from audit firms' organizational culture. The findings also showed that culture in such firms has a major role in processes determining the quality of audit and that audit firms can leverage enhanced cultures. In another related study, Kustinah (2013) demonstrated from his findings that it is important to understand organizational culture as it influences the audit quality of Certified Public Accountants. His findings showed that organizational culture positively and significantly influences on audit quality.

Moreover, Alzeban (2015) investigated the effect of different culture dimensions on internal audit, the results also showed that culture positively relates to internal auditing quality. In sum, prior studies reported a positive organizational culture-audit quality enhancement relationship, and related goals form organizational successes that will bring about improved performance, create competitive advantage and promote organizational prosperity.

\section{Impact of Organizational Culture on Audit Quality Assurance in The Public Sector}

Organizational culture is a crucial element of organizational success, particularly in TQM and quality improvement. It forms the optimum path for knowledge management and organizational innovation, as it determines the values and beliefs and work systems underlying the organization that could prevent or encourage knowledge creation and knowledge sharing.

In fact, the best place to initiate improvements in an organization is the assessment of its culture owing to culture's influence on individual and organizational behavior - thus, organizational culture is required for successful development of current organizations. In the context of audit firms, culture has a major role in the processes that underlie audit quality, and as such, audit firms should enhance their cultures.

Culture also has a major role in influencing the employees' actions - the way they communicate, team work and succeed in their performance. It is also a means to monitor employees and to keep their aims aligned with that of the firm's goals. By understanding the culture-quality relationship, managers may succeed in developing effective processes and competitive advantage.

With regards to the audit quality assurance determinants, they cover six factors namely peer review, auditor independence, auditor competence, accountability, auditor experience and internal review. These determinants are crucial to achieving the efficiency and effectiveness required in public sector organizations. Majority of studies showed that audit quality is frequently associated with peer review, competency, auditor independence, accountability, auditor experience and internal review in the detection of material misstatements and in being prepared to issue suitable audit reports. Such determinants can enhance engagement quality assurance and in turn, audit practices.

Nevertheless, quality assurance system implementation calls for a working framework that can be viewed as reference standard to ensure that the system is created and implemented in a structured, complete and 
effective manner. Past studies showed that auditing firms with quality assurance review programs displayed increased audit quality.

\section{Conclusions}

In the context of auditing, organizational culture facilitates the provision of optimum services, effective decision-making and the creation of competitive advantage and maintenance of prosperity. Culture forms the core of the activities of the firm and it influences its productivity, and its products and services in light of their quality. Therefore, culture is a pre-requisite of the development of a firm and it has a significant influence on the quality of audit. The finding of the present study showed that organizational culture is the heart of the organizational activities that has an effect on the organization's effectiveness and product/service quality.

Moreover, the audit quality assurance determinants contribute to obtaining clients' trust on the operations and services provided. Such determinants improve audit quality as they identify the significant weaknesses in public sector auditing. Such weaknesses are relayed to reviewers for rectification. In some studies, professional standards are considered to be the basis of quality assurance because the primary objective of audit quality assurance is to improve audit processes, minimize auditing failures, detect errors in the financial statements, and to enhance the profession's reputation in the eyes of the public.

\section{Reference}

[1] Adewale, O. O., \&Anthonia, A. A. (2013). Impact of Organizational Culture on Human Resource Practices: A Study of Selected Nigerian Private Universities. Journal of Competitiveness, 5(4), 115-133.

[2] Alkafaji, Y. A. (2007). Quality assurance review programs of auditing firms: an international perspective. Managerial Auditing Journal, 22(7), 644-660.

[3] Alzeban, A. (2014). Factors affecting the internal audit effectiveness: A survey of the Saudi public sector. Journal of International Accounting, Auditing and Taxation, 23(2), 74-86. http://dx.doi.org/10.1016/j.intaccaudtax.2014.06.001

[4] Asian Organization of Supreme Audit Institutions (2009) Quality Assurance in Financial Auditing, A Handbook, ASOSAI

[5] Badea, M. (2013). Cultural Influences In Human Resources Management. Review of General Management, (1), $179-187$.

[6] Buble, M. (2012). Interdependence of organizational culture and leadership styles in large firms. Management: Journal of Contemporary Management Issues, 17(2), 85-97.

[7] Clark, C., De Martinis, M., \&Krambia-Kapardis, M. (2007). Audit quality attributes of European Union supreme audit institutions. European Business Review, 19(1), 40-71.

[8] Cukier, W., Barkel, E., Vaughan, T., \& Gekas, G. (2012). Quality assurance in Canadian police services. The TQM Journal, 24(4), 295-309.

[9] Fuentes, C. M., Benavent, F. B., Moreno, M. A. E., Cruz, T. G., \&del Val, M. P. (2000). Analysis of the implementation of ISO 9000 quality assurance systems. Work study, 49(6), 229-241.

[10] Funnell, W. (1997), "The curse of Sisyphus: public sector audit independence in an age of economic rationalism", Australian Journal of Public Administration, Vol. 56 No. 4, pp. 87-105.

[11] Gold, A. H., Malhotra, A., \&Segars, A. H. (2001). Knowledge management: an organizational capabilities perspective. J. of Management Information Systems, 18(1), 185-214.

[12] HagmanMendonca, S., \&Persson, L. (2014). Audit Quality from a Client Company Perspective-Drivers of audit quality and the effects of a voluntary audit firm rotation.

[13] Ismail Al-Alawi, A., Yousif Al-Marzooqi, N., \&Fraidoon Mohammed, Y. (2007). Organizational culture and knowledge sharing: critical success factors. Journal of knowledge management, 11(2), 22-42.

[14] Karapetrovic, S., \&Willborn, W. (2000). Quality assurance and effectiveness of audit systems. International Journal of Quality \& Reliability Management, 17(6), 679-703.

[15] Kayrak, M. (2008). Evolving challenges for supreme audit institutions in struggling with corruption. Journal of Financial Crime, 15(1), 60-70.

[16] Knatterud, G. L., Rockhold, F. W., George, S. L., Barton, F. B., Davis, C. E., Fairweather, W. R., ... \& O’Neill, R. (1998). Guidelines for quality assurance in multicenter trials: a position paper. Controlled clinical trials, 19(5), 477-493.

[17] Kustinah, S. (2013). The Influence Of Dysfunctional Behavior And Individual Culture On Audit Quality. International Journal of Scientific \& Technology Research Volume, 2.

[18] Marais, M. (2004). Quality assurance in internal auditing: An analysis of the standards and guidelines implemented by the Institute of Internal Auditors (IIA). Meditari Accountancy Research, 12(2), 85-107.

[19] Morrison III, T. D., \&Shough, S. (2009). The impact of the new AICPA peer review standards on small CPA firms. In Allied Academies International Internet Conference (Vol. 11, p. 18).

[20] Park, H., Ribière, V., \& Schulte Jr, W. D. (2004). Critical attributes of organizational culture that promote knowledge management technology implementation success. Journal of Knowledge management, 8(3), 106-117.

[21] Russell, J., \& Armitage, J. (2006). Peer Review effectiveness: An analysis of potential loopholes within the USA Peer Review Program. Managerial Auditing Journal, 21(1), 46-62.

[22] Testa, M. R., \&Sipe, L. J. (2013). The Organizational Culture Audit: Countering Cultural Ambiguity in the Service Context. Open Journal of Leadership, 2(02), 36.

[23] Venter, J. M. P., \& Du Bruyn, R. (2002). Reviewing the internal auditing function: Processes and procedures. Meditari Accountancy Research, 10(1), 227-241.

[24] Wang, D., \& Hell, R. (2009). Cultural impact on the audit planning phase: An empirical study in China and France.

[25] Wright, R. M. (2009). Internal Audit, Internal Control and Organizational Culture (Doctoral dissertation, Victoria University). 